\title{
Globalization and perception of tourism trends by supply and demand
}

\author{
Pavlína Pellešová ${ }^{1, *}$ \\ ${ }^{1}$ Silesian University in Opava, School of Business Administration in Karvina, Univerzitní nám. \\ 1934/3, 7740 Karviná, Czech Republic
}

\begin{abstract}
The article deals with the development of trends in tourism, specified by selected authors, who describe trends. The aim of the paper is to compare trends in supply and demand. In the field of supply, we focused on the view of tourism business. Within the institutional support project Tourism Trends in the Moravian-Silesian Region, the impact of globalization on trends, both on the demand side and on the supply side, was analysed. Following methods were used: analysis, comparison, interview, questionnaire survey. The research revealed that most of the customers are affected by globalization, about half of the customers use the Internet to select and purchase travel agency services, one fifth use discount portals. Customers have also focused most on the following holiday trends: finding new experiences, active and adventurous trips, discovering unique places, gastronomic tourism, sightseeing and cycling. Based on the comparison of trends from the perspective of customers, travel agencies and the description of trends from the Tourism Management Strategy in the MSR 2017, it was found that traditional tourism, urban, cognitive and creative tourism, rural tourism, spa tourism are considered dominant, along with growing interest in gastronomic tourism, extreme experiences and adventure tours.
\end{abstract}

\section{Introduction}

Globally, tourism is considered the industry of the future. We are talking here about the global phenomenon of the present and according to Chalupa [1], it is a significant bearer of globalization processes. According to the Ministry for the Regional Development of the Czech Republic, see the Concept of the State Tourism Policy in the Czech Republic for 2014-2020, tourism is primarily a bearer of globalization processes. Its extent of internationalization is increasing both on the supply side (new destinations), and on the demand side (more and more people on the planet are involved in tourism). New, growing markets are emerging that change the notions of the nature of demand. Tourism is, according to the Strategy of Tourism Management in the Moravian-Silesian Region, the Update No. 1 complete version V2 (2017) a complex economic sector, which significantly affects employment, balance of payments and socio-economic development of regions, participates in gross domestic product creation, affects revenues of local budgets and also

\footnotetext{
*Corresponding author: pellesova@opf.slu.cz
} 
supports investment activity in the territory. Its development is accompanied by a multiplier effect that brings added value to the region. The primary objective of tourism is not merely to attract as many tourists/visitors to the region as possible and to increase the volume of investments in the territory.

Tourism is not only the cause of globalization processes, yet it is also influenced by them. There are many exogenous and endogenous effects on tourism, and one of them is trends. According to the Regional Authority of the Moravian-Silesian Region (MSR), tourism is the most dynamically developing economic sector in the world, and therefore its aim is to support it. The author of the paper focuses on the MSR and explores trends in tourism (within the institutional support project Trends in Tourism in the MSR).

Globalization can be generally defined as a global process, according to [2], as an external factor of the potential development of the region. Globalization has many dimensions, namely spiritual, security, political, economic, thus influencing the development of trends in tourism. The importance of tourism in the globalization process is specified [3]. Globalization is one of the 12 megatrends, according to UNWTO. These will affect international tourism by 2020 , such as promoting health, environmental, cultural, thematic and adventure tourism. From the perspective of globalization, tourism trends affect both the demand and supply side. They have an impact on the motives and trends that are favoured by the demand side and these are implemented in the product offers of tourism companies. Consequently, globalization also affects the perception of trends in individual regions, as evidenced by the research carried out.

\section{Methods}

Data was obtained by primary research, through professional publications, journals, and conference proceedings. The research was carried out in 2017 and 2018 by electronic questioning. The method of analysis, synthesis, comparison, generalization and deduction, the technique of the structured interview and the questionnaire survey were used to gain information about the attitude of customers and companies in tourism to the researched issue. From a methodological point of view, the article is also based on a statistical analysis of available data, based on the frequency of responses. To determine the development of trends criteria were determined based on the description of trends according to the Tourism Management Strategy in the MSR [4]. From the research preferences of trends on the demand and supply side were derived, which were compared. Demand-side preferences allow tourism companies to tailor their supply to reflect current trends. The result is the determination of tourism trends and a proposal of recommendations for the direction of supply development for business entities in the Moravian-Silesian Region.

\section{Trends from the point of view of theory and practice}

\subsection{Theoretical bases of the trends in tourism}

Trends also arise in the field of tourism and affect the motivation and incentives of future visitors to travel; these are long-term trends in the development of the region. Global megatrends also include the mutual conditionality of globalization and localization, the deepening of polarization of tourists' preferences oriented to comfort and adventure, a shrinking world for tourism, a growing dominance of buyers, and a destination choice can be of social importance - destinations as fashion accessories, with an emphasis on marketing and product creation. Trends in tourism are addressed by many authors, e.g. [5, $6,7,8]$. Demand in tourism and trends is addressed by Plesník [9]. The use of new technologies is considered useful in improving the forecast of tourism demand and Onder 
[10]. Buhalis [11] discusses supply of tourism. Rapid technological changes are changing the consumer's view of the tourism product [12].

Vetráková et al. [13] stress the need for tertiary education in the light of new tourism trends. The importance of multiplication effects of tourism in the region is described by Bunghez, Pellešová, Duro, $[14,15,16]$ etc. The Internet has become a major tool for finding information. This also applies to the tourism industry, where we are increasingly encountering online search.

\subsection{A practical perspective on trends in tourism}

The Action Plan for the Development of Tourism for 2018/2019 [17] is based on the Tourism Management Strategy in the MSR, which was established in 2014-2015. Its aim is to set priorities for the development of tourism in the MSR for 2018 (overlapping until 2019). The projects are strategically focused on sports tourism - cycling and cross-country skiing tourism, industrial tourism and gastrotourism.

According to the Tourism Management Strategy of the MSR for the years 2015-2020 [18]:

- Traditional tourism dominates in the territory of the MSR, such as urban, sightseeing and creative tourism, rural tourism, wellness, spa. New forms are also developing, especially couch surfing, industrial tourism, event tourism, gastronomic tourism, adventure tourism (sports), geocaching, tourism focused on seniors.

- The MSR's attendance is seasonal in nature, with the highest number of guests coming to the region in summer

- Since 2006, the number of guests interested in more expensive and luxury accommodation (four-star hotels/motels), B\&B establishments has been increasing; the number of visitors searching for cheap forms of accommodation in tourist hostels, camps, and two-star hotels has been decreasing. Tourists are increasingly interested in active holidays, demand for off season activities, providing product packages - especially young and active people want to assemble their package themselves.

- The Internet is the main communication channel.

- Individualization of tourism - growth in demand for smaller accommodation units, individual travel.

- A specific feature of the region is the conditions for industrial tourism. The Beskydy and Jeseníky Mountains have the greatest potential for tourism development.

- Absence of accommodation capacities in the area of Hlučín, Opava, Krnov, Poodří, and Osoblaha.

In the years 2017-2018, the destination company (Moravian-Silesian Tourism, s.r.o) conducted a survey "The analysis of the visitor profile of the tourist region Northern Moravia and Silesia". The sample included more than 1,700 respondents, the Department of Tourism and Leisure Time Activities of the SU in Opava, the School of Business Administration in Karviná participated in it, too. Research results are as follows:

- Visitors come to the MSR most often with family (60\%) and friends (19\%).

- The main reasons for the visit are knowledge (53\%), rest and recreation (51\%), tourism and sport (46\%).

- Most respondents (46\%) have already visited the MSR and have a good experience, $30 \%$ of the respondents learned about the MSR from the recommendations of friends and the closest friends, $24 \%$ from the destination website and a tenth from media advertising. 
- The cost per day of stay is usually CZK 500-1000 (34\%), CZK 200-500 (31\%), CZK $1000-2000$ ( $15 \%$ of respondents).

- The most respondents (44\%) responded to the question about the visitors' experience in the region (44\%), active movement in pure nature, cycling or walking, followed by contrasting industrial tradition and beautiful nature $(31 \%)$. For $23 \%$ of the respondents, a visit to the MSR is a place where pleasant and accommodating people live, stop and enjoy peace, the harmony of soul and nature, $22 \%$ of visitors come to know the traditions they want to show to their children/grandchildren.

Current trends in tourism are presented in the Strategy of Tourism Management in the Moravian-Silesian Region, the complete Version 2, updated from 2017 [4]. According to it, one of the prerequisites for increasing the quality and efficiency of tourism management is to establish regional marketing initiatives around the world. The current trends in tourism according to the strategy include:

- The Internet as the most frequent and most important source of information, word of mouth and personal recommendations,

- The Internet as the main communication channel - online reviews influence online decision making, accommodation websites facilities, tourist areas and tourist attractions - the form of the presentation on the websites is important,

- Increase in online sales of individual products and services, tourism and an increase in the number of direct bookings (without the use of tour operators - a decline of their importance),

- Increase in the number of tourists in older (senior) age and young people (16 to 35 years),

- Individualization of tourism - growth in demand for smaller accommodation units, for individual travel,

- The dominant role played by car transport,

- Shortening of "main" holidays, more short-term holidays,

- Growth in demand for off season activities,

- Growth in requirements of tourists/visitors on services (quality/price ratio), the development of experiential tourism,

- A growing interest in active holidays, wellness products, spa stays and fitness centres,

- Growth in demand for leisure activities and relaxation (relaxing stays),

- Providing product packages, especially active and young people want to assemble their package themselves,

- Development of new forms of tourism, e.g. urban tourism, event tourism, industrial tourism, gastronomic tourism, experiential tourism, couch surfing, geocaching, etc.,

- The use of mobile applications (satellite navigation, information SMS, MMS postcards),

- Brand management (the key element is no longer the brand of a specific destination, but then again, the brand of the entire location - city, region),

- Seasonal attendance to the region (the highest number of visitors in the summer season).

\subsection{Research of trends in tourism in the MSR}

Within the institutional support project Trends in Tourism in the Moravian-Silesian Region, the researchers focused on predicting and detecting the development of tourism trends in the region on the demand and supply side. The research was conducted in 2017 and 2018 
by electronic questioning, structured interviews took place in 2018 and early 2019. The sample of respondents on the demand side was 334 potential customers and on the supply side 68 catering establishments, 37 accommodation businesses and 29 tour operators and travel agencies (TO/TA) in the researched region. The project team also conducted structured interviews with 45 representatives of business entities in the MSR (small and medium-sized enterprises). The aim of the researches was to obtain and analyse the respondents' opinions on the side of supply and demand on tourism trends, their monitoring, importance, and benefits.

Research of respondents (customers) in the area of catering establishments shows that the use of novelties in the offer is important for about $35 \%$ of respondents and not important for about a quarter. $57 \%$ of respondents often or sometimes try the novelties in the offer. Respondents would like to experience trends such as fusion of food with drink, exotic menu, tea and coffee tasting, foreign cuisine days, edible flowers, rational menu, famous drinks, wine tasting. Mobile applications are also used for faster check-in, easier payment, etc. From special offer respondents tried following: days of foreign cuisine, venison feast, pig slaughter feast, trendy drinks, mediaeval tavern, then wine degustation, tea and coffee tasting, Raw food menu. Serving decide about repetitive restauration visit (1 - mainly professional behaviour, knowledge of the offer and ability to give maximum information, empathic approach), restaurant environment $(2$ - primarily cleanness and tidiness, light and warm comfort, air pollution), within the enterprise offer (3) corresponding price/quality ratio, acceptable prices, possibility of online reservation or acquaintances recommendation play main role. Respondents use mobile applications for restaurants, that help with faster clearance, easier payment, etc. The surveyed devices follow new trends and are introduced into the offer (75\%), for about $44 \%$ of companies the implementation of trends is necessary, and the same percentage reflects financial possibilities. In structured interviews, business representatives responded to the question (whether they are focusing on introducing modern trends into the menu that introduces the novelties and with what effect) and their answer was: we introduce gluten-free meals, raw food; we introduce special and seasonal menu as well as new recipes, local dishes, and mainly fresh dishes. Modern styles were the focus of the restaurants: bio, sous-vide, edible flowers, molecular gastronomy, vegan cuisine, front cooking, with catering establishments, then a wellness offer, action packages and the introduction of loyalty cards.

Furthermore, trends in the area of accommodation were researched. Occasionally, 1/3 of respondents used reservation systems and $40 \%$ of respondents always did. $52 \%$ of respondents preferred contact with accommodation. Respondents stay in accommodation facilities in the MSR once a year (approx. 13\%), 3 times - more times a year (approx. 17\%). For repeated visit of an accommodation facility following things are important regarding staff: professional behaviour, knowledge of the offer and ability to give maximum information, speed of service; regarding environment: cleanness and tidiness, parking possibilities, interior design; regarding an offer: corresponding price/quality ratio, acceptable prices, possibility of online reservation, acquaintances recommendation, Wi-Fi, online reviews. Approximately $62 \%$ of respondents use or occasionally used TO services to secure accommodation. Clients would welcome a new wellness facility, benefits for regular customers, any investment in the interior renewal, a modern fitness, and updates on the website $^{\dagger}$. Accommodation establishments follow modern trends and introduce them into the offer (approx. 60\%), when introducing trends financial possibilities are taken into account by $54 \%$ of companies, for $43 \%$ of companies the implementation of trends is necessary and

\footnotetext{
${ }^{\dagger}$ Clients also use mobile applications of shared accommodation or transport services such as Airbnb, Uber, etc. Respondents use discount portals (one fifth), such as Slevomat, Hyperslevy.cz, Pepa.cz, Zapakatel.cz, Cestuj.cz, Slevoking. cz, Skrz.cz.
} 
approximately one-third of companies adhere to proven offers. The focus of business representatives within structured interviews were the following trends: a wellness offers, action packages and the introduction of loyalty cards.

The third part of the research was directed to the services of tour operators/agencies (TO/A). Respondents learned about the TO/TA from the Internet $(60 \%)$, personal recommendations $(22 \%)$ and about a tenth from promotional materials. About $52 \%$ of respondents use the Internet to select and purchase TO/TA services, and about a fifth of respondents use the offer of discount portals. Air transport (49\% of respondents) is preferred to own transport (35\%). When choosing a holiday, respondents focused most on the following trends: searching for new experiences (1), active and adventure trips and discovering unique places (2), sightseeing (3), health and spa tourism (4). Travel agencies focus on the following trends: seeking new experiences (1), active and adventure trips, senior tourism, sightseeing (2), youth tourism (3), segment 55+, short term stays in Europe (4), relaxation and rest (5).

The carried-out research proves that for the creation of tourism supply it is necessary to start from the assumptions of the region, its attractiveness, accessibility, changing demand, the demographic composition of the population, which differ significantly from other parts of the country. The research showed that most of the respondents were influenced by globalization and trends in tourism. Based on a comparison of trends from the perspective of customers, surveyed companies and description of trends from the Tourism Management Strategy in the MSR 2017, the following were ranked among the most important trends in tourism in the MSR:

- The internet as a source of information, communication channel, and tool, the presentation form is important, the impact of online-reviews,

- Growth in online sales, growth in direct bookings, the importance of acquaintances' recommendations,

- Growth in the number of senior citizens and young people,

- The individualisation of tourism,

- Air transport and then one's own transport play a dominant role,

- More short-term holidays, a significant proportion of overnight visitors, often off season, seasonal visits to the region,

- Growth in tourist/visitor requests for services (quality/price ratio),

- Development of experiential tourism, growth in active holidays, wellness, spa stays and fitness, development of new forms of tourism such as urban tourism, event tourism, industrial, gastronomic, experiential tourism, couchsurfing, ...,

- Providing product packages,

- Using mobile applications.

\section{Discussion}

In order to predict trends in the MSR, it is necessary to take into account the disposition of the region, its attractiveness and accessibility, the changing demographic structure of the population, and the perception of trends by tourism companies themselves. New technologies and modern trends are part of the everyday life of customers and play an important role in the light of tourism trends. What is important for identifying trends in tourism? How are they applied?

- Monitoring changes in customers' perceptions, needs, and preferences,

- Using modern communication,

- Promoting online offers,

- Following service references provided,

- Monitoring competition, 
- Innovating offers and introducing new trends, ...

\section{Conclusion}

Research on tourism trends in the MSR has led to the identification of trends in tourism in terms of both demand and supply. Formulating development trends, with an emphasis on newly identified trends, will serve business entities and institutions engaged in the planning of tourism development in the region as a recommendation for the direction of the creation of new products and events for increasing tourist visits to the region. This will enable tourism companies to tailor their offers to respond to trends from a global perspective.

Based on the analysis of the impact of globalization on trends in demand in tourism, it was found that customers (generating demand) use discount portals, place great emphasis on quality, original and unconventional experiences, comfort, safety, and show an increased interest in wellness and health stays, discover unique places, enjoy gastronomic tourism, sightseeing, and cycling, and prefer air travel. Almost half of the business representatives surveyed stated that the introduction of new trends was a necessity for success and needed to be monitored and adapted. Only a small proportion of respondents $(4 \%)$ said that they did not introduce anything new, because guests were satisfied with the current offer, $4 \%$ of respondents followed tradition. According to $22 \%$ of respondents, it is necessary to monitor the needs of customers. Introducing new products into the offer and following modern trends increases attendance and sales (57\%) and improves the image and public interest $(2 / 5$ of respondents). The most significant trends in tourism in the MSR have been identified from the comparison of theoretical knowledge, research results and the Tourism Management Strategy in the MSR. Most people agree with the stated tourism strategy and some of the trends coincide with the developmental trends presented by theorists, but also by tourism institutions and organizations. However, these are subject to changing conditions and evolution.

The article was created with the support of the Ministry of Education, Youth and Sports of the Czech Republic in the framework of Institutional Support for the Long-Term Conceptual Development of the Research Organization in 2017-2019.

\section{References}

1. P. Chalupa, Topical Issues of Tourism, 130-139 (2015)

2. C. L. Bunghez, The Importance of Tourism to a Destination's Economy (IBIMA, I VI, 240-247, 2015)

3. J. Botlík, M. Botlíková, The development of tourism consumption in catering (International Scientific Conference on Globalization and its Socio-Economic Consequences, 247-254, 2016)

4. L. Hruška, kol., Strategie řízení cestovního ruchu v Moravskoslezském kraji (Url: https://www.msk.cz/assets/rozvoj_kraje/strategie-rizeni-cestovniho-ruchu-vmoravskoslezskem-kraji---aktualizace-c--1.pdf, 2017)

5. O. Claveria, E. Monte, S. Torra, Common trends in international tourism demand: Are they useful to improve tourism predictions? Tourism Management Perspectives, 16, 116-122 (2015)

6. S. Gardiner, Journal of Travel Research, 53, 705-720 (2014)

7. E. Csirmaz, K. Peto, International trends in recreational and wellness tourism. $E M Q F B, 32,755-762$ (2015) 
8. G. Richards, Cultural tourism: A review of recent research and trends. Journal of Hospitality and Tourism Management. Journal of Hospitality and Tourism Management, 36, 12-21 (2018)

9. P. Plesník, New Trends in Tourism Demand - Geocaching. International Conference on Topical Issues of Tourism Location, 371-378 (2015)

10. I. Onder, Forecasting Tourism Demand with Google Trends: Accuracy Comparison of Countries versus Cities. International Journal of Tourism Research, 19, 648-660 (2017)

11. D. Buhalis, et. al., A model of perceived image, memorable tourism experiences and revisit intention. Journal of Destination Marketing \& Management, 8, 326-336 (2018)

12. J. Bowen, E. Whalen, Trends that are Changing Travel and Tourism. Worldwide Hospitality and Tourism Themes, 9, 592-602 (2017)

13. M. Vetráková M. Gúčik, J. Kučerová, Tertiary Tourism Education in the Light of New Trends. International Conference on Topical Issues of Tourism, 71-81 (2015)

14. C. L. Bunghez, The Importance of Tourism to a Destination's Economy. IBIMA, 240247 (2015)

15. P. Pellešová, Tourism and Multiplication Effects in the Region. Business Information Management Assoc., 515-520 (2015)

16. J. A. Duro, Seasonality of tourism: A new decomposition. Tourism economics, 24, 615-621 (2018)

17. J. SMIGA, Akční plán rozvoje cestovního ruchu pro rok 2018. Available at: https://www.msk.cz/cz/rozvoj_kraje/akcni-plan-rozvoje-cestovniho-ruchu-pro-rok2018-111105/ (2018)

18. MSK, Strategie řízení cestovního ruchu v Moravskoslezském kraji na léta 2015 až 2020. Available at: https://www.msk.cz/cz/rozvoj_kraje/strategie-rizeni-cestovnihoruchu-v-moravskoslezskem-kraji-2015-72089/ (2015) 